\title{
Development and Popularisation of Agathi Leaves (Sesbaniagrandiflora) Incorporated Food Products
}

\author{
Samja Sabu ${ }^{1}$, Aparna S Gopakumar ${ }^{2}$ \\ ${ }^{I}$ (UG Student, Department of Home Science, Vimala College, University of Calicut, India) ${ }^{2}$ (Lecturer, Dept.of \\ Home Science, Vimala College, University of Calicut, India)
}

\begin{abstract}
The present study entitled 'Development and Popularization of Agathi leaves (Sesbaniagrandiflora) Incorporated Food Products' was done with an aim to prepare Agathi incorporated products, to study their shelf life qualities and to popularize these products among women attending self-help groups like Kudumbasree units. The study also measured awareness of the Kudumbasree members about Agathi.

In order to meet the objectives, fifteen products were prepared by incorporating Agathi leaves namely Agathi mango jujubes, Agathi tomato sauce, Agathi pineapple jam, Agathi sweet pickle, Agathi pickle, Agathi cutlet, Agathi dry chutney powder, Agathi wet chutney, Agathipathiri, Agathi green gram dosa, Agathi water melon drink, Agathi halva, Agathi tomato squash, Agathi lemon juice and Agathi cucumber mix. These products were prepared in three variations namely variation $A$, variation $B$ and variation $C$ which contained various proportions of Agathi, incorporated in 20 per cent, 30 per cent and 50 percent in them along with other ingredients for achieving enhanced quality and adequate quantity of the nutrients in the products.

A score card was prepared to select the judging panel of five members. Another five point score card was prepared to evaluate the sensory qualities of the prepared products. Organoleptic evaluations of the sensory qualities of the prepared products were done by employing the triangle test. Among the prepared variations, those variations with highest overall acceptability scores were considered as the best variation of the product.

The nutrient content of the best variation of each Agathi incorporated product per $100 \mathrm{~g}$ was assessed with reference to their energy, carbohydrates, protein, fat, calcium, $\beta$-carotene and vitamin $C$ content. Agathi incorporated products were found to be rich in nutrients especially vitamin $C$, calcium and $\beta$-carotene, while it supplied fewer amounts of calorie, carbohydrate and fat.

The developed products were analyzed for their shelf life qualities for a period of 6 months at room temperature. Thebestvariations of each Agathi incorporated product were also evaluated for the time taken in preparing them.

Among the developed products, two of the best product variation with highest overall acceptability scores namely Agathi pineapple (4.72) jam and Agathi dry chutney powder (4.80) were popularized among two Kudumbasree units. For the process of popularization, a questionnaire which collected information about the awareness of Agathi leaves, a brochure which explained the nutritional and medicinal benefits of Agathi, a score card for the sensory evaluation of Agathi incorporated products and a questionnaire which collected the feedback from the Kudumbasree members were prepared and presented. Each product were then organoleptically scored by the respondentsthrough a score card, which were then compared with the scores for the products given by the judging panel, which showed no significant differences. The responses given by the Kudumbasree members showed that they had the interest to cultivate Agathi and also to incorporate Agathi leaves in their daily diet.
\end{abstract}

Keywords: Green leafy vegetables, Kudumbasree, Nutrients, Score card, Shelf life

\section{Introduction}

Vegetables comprise a large number of plants, mostly annual, of which different parts like leaves, stem, flowers, fruits, roots etc. are eaten. They are rich in nutrients and are essential items of a balanced diet. Among the vegetables, green leafy vegetables are a food group which is nutrient dense.

Many green leafy vegetables can be found in today's market and most of them are traditionally used by a particular culture, outside of which they are barely known. Among them, Sesbaniagrandiflora, often described as "A green leaf with curative benefits", is a relatively unknown plant which is not easily available outside tropical countries. Although Agathi trees are widely distributed in India, it is not so popular among the people. It is cultivated in states like Assam, Bengal, Punjab, Andhra Pradesh and Tamil Nadu.

In the indigenous system of medicine in India, the plant Agathi is claimed to be useful for various ailments and one such is for the treatment of renal calculi. Generally the green leaves of this variety is used for cooking similar to spinach but the flower, leaf and bark of Agathi tree has got a number of medicinal properties which is used in various ayurvedic and other traditional medicines. The simplest manner in which these leaves are used is by boiling the leaves with water to make a tea, which bears antibiotic, antihelminthic and antitumoral 
properties. For all sorts of sprains and bruises, Sesbaniagrandiflora's crushed leaves can be applied and the juice acts as a good medical treatment. Thus all parts of this unique plant are useful. It is also used as an antidote for poisons. The plant has various uses in folk and traditional medicines for head ache, swellings, anemia, bronchitis, pain and tumors.

In Kerala, although it is grown widely and is often used as a green manure or forage, its culinary qualities and medicinal properties are not popular among the people. The interest in the cultivation and utilization of Agathi leaves has to be promoted, powered by progressive research efforts to identify the properties and potential application of this plant. For this it is necessary to increase public interest and consumer demand.

Diet is a vital determinant of health and nutritional status of the people ${ }^{[1]}$. In the present situation, lifestyle diseases are increasing because of globalization and trends in which our people are adopting the food styles of western community. The life style diseases like cardio vascular diseases, diabetes, hypertension etc. are more prevalent among people in Kerala. Agathi is both a green leafy vegetable as well as a medicinal plant which plays a major role in controlling those diseases and the people are not aware about their culinary application.

Thus cooking with Agathi leaves unveils some of the mystery behind those leaves. What people need is practical information regarding the use of some of these less common leaves one comes across at the market. Thus in the current scenario, there is a need for promoting the popularity of nutritionally and medically beneficial Agathi leaves among the people to encourage its use.

Looking to the importance of Agathi, it is desired that there should be a well chalked out plan to cover Agathi plants under various research projects to generate the information on various aspects so that commercial cultivation of Agathi can be popularized [2]. Highlighting these facts the present study entitled "The Development and Popularization of Agathi (Sesbaniagrandiflora) Incorporated Products" describes in detail the culinary as well as the therapeutic properties of Agathi leaves through the development of Agathi incorporated recipes and their popularization, which helps the people to prepare delicious and nourishing dishes with Agathi.

\section{Methodology}

Methodology of the study entitled 'Development and Popularization of Agathi leaves Incorporated Products' involves the following steps:

\subsection{Development of indigenous products based on Agathi leaves (Sesbaniagrandiflora) \\ 2.1.1. Selection of Agathi leaves for the study}

Sesbaniagrandiflora commonly called Agathi, is a nutrient rich green leafy vegetable. They are not much available and they can be cultivated in a cheap and easy way. Most of the people were ignorant about the nutritive value of Agathi. Agathi leaves consumption rate among the people was very less and availability was also found to be less. Thus among green leafy vegetables, Agathi was chosen for the study which involves development of Agathi leaves incorporated recipes and its popularization, among women belonging to self- help groups like Kudumbasree units.

\subsubsection{Cultivation of Agathi for the study}

The seeds of Agathi plant were purchased from a local market. It was sown in the month of September. For sowing the seed of Agathi, at first the soil was prepared by mixing bio fertilizers with it. After two days the sprout came out from the soil and seedlings began to grow. Cultivation was done in the month of October. Pest attack was much less and needed minimal irrigation facilities.

\subsubsection{Selection of recipes for Agathi leaves incorporation}

Twenty recipes suitable for Agathi leaves incorporation were collected and 15 ideal recipes were selected for the study. The recipes selected for incorporation were jujubes, sauce, jam, sweet pickle, pickle, cutlet, dry chutney powder, wet chutney, pathiri, green gram dosa, halva, watermelon drink, tomato squash, lime juice and cucumber mix.

\subsubsection{Organoleptic evaluation of incorporated products}

Quality is the ultimate criterion of the desirability of any food product ${ }^{[3]}$. Organoleptic evaluation is a scientific discipline used to evoke, measure and analyze reactions to those characteristics of products or material as they are perceived by the sense of sight, smell, taste, touch and hearing ${ }^{[4]}$. The developed products were evaluated organoleptically to assess their sensory qualities. 


\subsubsection{Selection of judging panel}

To assess the acceptability of the products through sensory evaluation, a panel of 5judges was selected. The selection criteria for the panel members were their ability to perceive and recognize the variations in the quality of different food items. For the selection of panel members serial dilution test ${ }^{[3]}$ was used. A small highly sensitive panel would give more reliable results than large less sensitive groups. Five of the participants who got highest scores were selected as the judging panel

\subsubsection{Formulation of different combination of products and selecting the best one}

Before the preparation of the items, Agathi leaves were exposed to different pretreatments like dehydration, extraction of juice, soaking etc. according to the need.

Three different variations of each product were prepared with Agathi leaves incorporated at 20,30, and 50 per cent. The incorporated products were evaluated organoleptically by the selected judging panel.

\subsubsection{Standardization and sensory evaluation of the developed products}

The Agathi leaves and juice were incorporated at percentages of 20,30 and 50 to the selected products to form three variations each namely A, B, and C. Triangle test was employed for selecting the best variation out of the three ${ }^{[3]}$. In this test, a five point score card which evaluates the factors like taste, color, flavor, texture and appearance were given to the judging panel. Each members of the judging panel tasted and evaluated the products and marked their score in the score card.

\subsection{Nutritive value of formulated recipes}

The nutrient content of the developed products per $100 \mathrm{~g}$ were calculated using Nutrient Composition Table $^{[5]}$ with reference to their Energy, Carbohydrates, Protein, Fat, Calcium, $\beta$ - carotene and Vitamin $C$ content.

\subsection{Shelf life study}

The developed products were analyzed for their shelf stability for a period of 6 months. The variations of each prepared products were stored in glass bottles at room temperature and were analyzed for their shelf life. During the storage period, the bottles were examined visually for detecting any color change or microbial deterioration. At the end of each month, one set of each variation of the stored products was evaluated for their sensory qualities also.

\subsection{Evaluation of time for the preparation of Agathi leaves incorporated food products}

The time taken for preparing $100 \mathrm{~g}$ of each products with higher overall acceptability scores were assessed for measuring the easiness with which the products were prepared. It was calculated on the basis of the time taken for preliminary preparations and the time taken for cooking the products.

\subsection{Popularization of products}

Out of the fifteen developed products, two products which obtained the highest scores were popularized among two selected women self- help groups like Kudumbasree units.

\subsubsection{Selection of products for popularization}

For the purpose of popularization, two best recipes were selected from the fifteen Agathi incorporated products. The two products which got the highest score for overall acceptability when organoleptically evaluated were selected for popularization.

\subsubsection{Selection of consumer group for the popularization of products}

Agathi incorporated recipes were popularized among women belonging to self-help groups like Kudumbasree, through demonstrations and lectures, thus encouraging them to start consuming Agathi which have high medicinal and nutritive value, in easier and cost effective ways.

\subsubsection{Formulation of brochure and charts for popularization}

Brochure and charts which contained necessary information, nutritional benefits and medicinal uses of Agathi were prepared and given to the members of Kudumbasree units for the process of popularization.

\subsubsection{Formulation of questionnaires for popularization}

For the process of popularization, questionnaires were prepared to checking the awareness of the Kudumbasree members about Agathi leaves and to collect the details regarding the extent of knowledge, the consumers attained through the lecture. 


\subsubsection{Evaluation of consumer acceptance through sensory evaluation}

For assessing the consumer acceptability of the popularized products, a score card with five points for quality attributes like appearance, flavor, texture, taste and color was prepared. The scores obtained through popularization were then compared with the scores given by the judging panel for the same products.

\section{Results And Discussion}

Salient features of the study entitled 'Development and Popularization of Agathi leaves (Sesbaniagrandiflora) Incorporated Food Products can be discussed under the following headings:

\subsection{Organoleptic evaluation of Agathi leaves incorporated products}

Organoleptic evaluation was done for the three variations of each product to find out the best variation out of the three using the triangle test. This test employs three samples, containing main ingredients especially Agathi, in different percentages. The judges were asked to determine the best of the three variations of each product using a five point score card.

The mean score of the all the quality attributes of a variation was taken as the overall the acceptability score of that variation. The variation with the highest overall acceptability score taken was as the best variation of the product prepared incorporating Agathi.

Among the developed products, Variation B of Agathi pine apple jam (4.76) and Variation C (4.80) of Agathi dry chutney powder obtained the highest scores for over all acceptability. Also the products obtained best scores for sensory qualities like appearance, flavor, taste, texture and color.

\section{Agathi mango jujubes}

Jujubes are small fruit flavored candy with a hard gelatinous center ${ }^{[6]}$. The best variation of Agathi mango jujubes was found to be variation B. Variation B obtained the highest score (4.00) for over all acceptability when compared to the other two variations. This variation was prepared by mixing 20 per cent Agathi juice and 80 per cent raw mango juice. Thus the combination of sweet and sour was best in Variation B. The consistency of variation B was also found to be of superior quality.

\section{Agathi tomato sauce}

The best variation of Agathi tomato sauce was found to be Variation $C$ which was made with 30 per cent Agathi juice and 70 per cent tomato pulp. Over all acceptability of variation $\mathrm{C}$ was the highest and the best with a score of 4.28 .

\section{Agathi pine apple jam}

In the case of Agathi pineapple jam, the best variation was variation B. It was prepared with 20 per cent of Agathi juice extract and 80 per cent of pine apple pulp. Variation B got the best overall acceptability score of 4.72. The combinations of flavors were good in variation B and the consistency was also superior to others. During jam making, sucrose and glucose syrup (15\% of total sugar) are added in quantities equivalent to the fruit pulp used for preparing it ${ }^{[7]}$.

\section{Agathi Sweet Pickle}

Quick and simple to prepare, the sweet pickle form a recipe which you can make when you are short on time ${ }^{[8]}$. The best variation of sweet pickle was variation B with an overall acceptability score of 4.64 . This variation was prepared by incorporating 20 per cent of Agathi and 50 per cent of dates.

\section{Agathi pickle}

The best variation of Agathi pickle was found to be Variation A with a score of (4.20) for over all acceptability. It was made by incorporating 20 per cent of Agathi leaves with 80 per cent of other constituents like garlic and tomato. For pickles, the acidity or salinity of the solution, temperature of fermentation and the exclusion of oxygen determine which microorganism dominate, and determine the flavor of the end product ${ }^{[9]}$.

\section{Agathi cutlet}

In the case of Agathi cutlet, variation A obtained the highest overall acceptability score of 4.20 . The variation was made by incorporating 30 per cent of Agathi leaves with 70 per cent of other vegetables.

\section{Agathi dry chutney powder}

Dry chutney comes in the form of coarse or smooth powders. Chilies form an integral part of most chutney recipes ${ }^{[10]}$. Agathi chutney powder was smooth in texture. The best variation of dry chutney powder 
was variation $\mathrm{C}$, with a score of 4.80. Variation $\mathrm{C}$ was made by incorporating 50 per cent of Agathi leaves with 50 per cent of coconut.

\section{Agathi wet chutney}

Among the 3 variations of Agathi wet chutney, the best variation was found to be variation $\mathrm{C}$ with an overall acceptability score of 4.16 . The variation $C$ contained 50 per cent of Agathi juice and 50 per cent of coconut. Wet chutney was spicy in nature and it can be used as a combination for many breakfast items like dosa and idli. Wet chutney is often made for instant consumption without the use of any preservative ${ }^{[11]}$.

\section{Agathipathiri}

Pathiri is a type of bread served with Indian foods, but it is delicious with any soup, stew or meat because of its rice base ${ }^{[12]}$. For Agathipathiri, the best variation was found to be variation A. The variation A obtained a score of 4.20 for overall acceptability. It was made by incorporating 20 per cent of Agathi leaves in 80 per cent of rice flour.

\section{Agathi green gram dosa}

Dosa is one of the most popular traditional South Indian foods. It is a breakfast food made from the batter of ground rice, black gram and water, which is allowed to ferment at temperature between 313-318 $\mathrm{K}^{[13]}$.In the case of Agathi green gram dosa, the best variation was found to be variation A. The variation A contained 50 per cent of Agathi leaves and 50 per cent of green gram.

\section{Agathi halva}

Halva resembles confectionary jelly in texture. Starch being an important glucose polymer is a main jelling agent in the halva ${ }^{[14]}$. Among the 3 variations of halva, variation $C$ was found to be the best variation with a score of 3.30 for over all acceptability. It was prepared by incorporating 20 per cent of Agathi juice and 80 per cent of milk and rice flour mix.

\section{Agathi watermelon drink}

The best variation of Agathi water melon drink was variation B with a score of 3.6 for overall acceptability. The variation was prepared by incorporating 30 per cent of Agathi juice and 70 per cent of watermelon. Variation B was the best variation because the taste and texture was superior when compared with other variations.

\section{Agathi tomato squash}

Among the three variations of squash prepared, variation $\mathrm{C}$ was found to be the best variation with a score of 4.52. The variation was prepared by incorporating 50 per cent Agathi juice and 50 per cent tomato pulp. Double the amount of sugar was also added to this. The consistency of squash was that of perfect syrup and it was sweet because of the addition of double amount of sugar, than fruit syrup.

\section{Agathi lemon juice}

Out of the three variations of Agathi lemon juice, variation A was found to be the best variation with a mean score of 4.52 for overall acceptability. The prepared variation was made of 30 per cent Agathi juice incorporated with 70 per cent lemon juice and water. Lemon squash drink or hot lemon with sugar and salt added is a good dehydration solution ${ }^{[15]}$.

\section{Agathi cucumber mix}

From the three variations of Agathi cucumber mix, variation $\mathrm{C}$ was found to be the best variation with a score of 4.04 for overall acceptability. The variation $C$ was made by mixing 20 per cent of Agathi juice, 80 per cent of cucumber, water and salt. Cucumber is good for thirst because it contains $96.3 \mathrm{~g}$ of moisture ${ }^{[5]}$. Hence it was suitable to incorporate cucumber with Agathi in correct proportion.

The Fig. 1 represents the percentage of overall acceptability score over the total scores of the product variations with highest score. Among these products, Agathi dry chutney powder (variation C) got the highest percentage of score of about 96.00 followed by Agathi pine apple jam (variation B) with a percentage of score 94.40. Agathi halva was the product which obtained a least percentage score of 66 . 


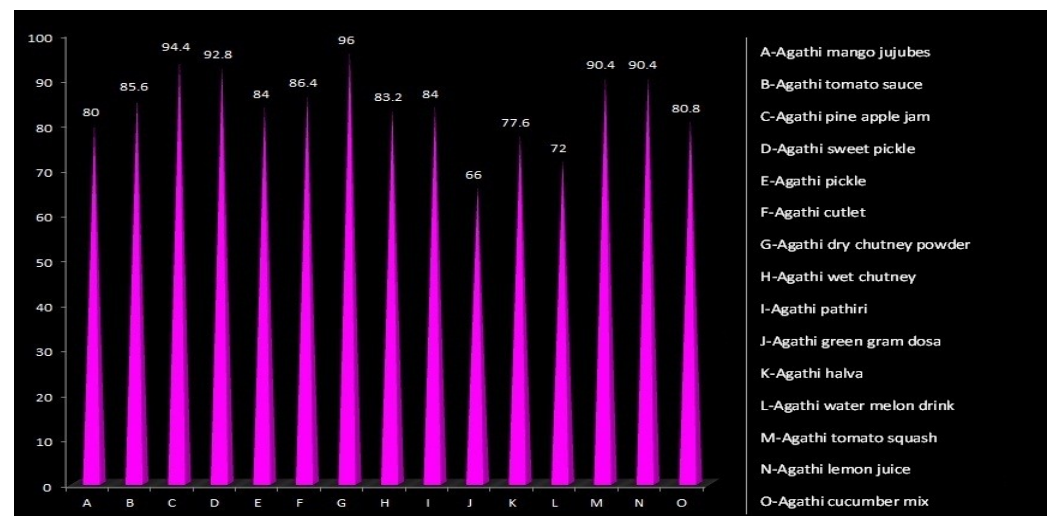

Fig.1 Percentage of overall acceptability scores over the total score

\subsection{Nutrient composition of Agathi incorporated products}

The nutritive value of $100 \mathrm{~g}$ of each product variation with the best acceptability scores were calculated based on Nutrient Composition Table $\mathrm{e}^{[5]}$ to find out its calories ,carbohydrates, proteins, fat, calcium, B- carotene and vitamin $\mathrm{C}$ content. The results are depicted in TABLE 1.

\section{TABLE.1 Nutrient composition of Agathi incorporated food products (per $100 \mathrm{~g}$ )}

\begin{tabular}{|l|c|c|c|c|c|c|c|}
\hline \multicolumn{1}{|c|}{ Product name } & $\begin{array}{c}\text { Energy } \\
\mathbf{( K c a l )}\end{array}$ & $\begin{array}{c}\text { Carbo- } \\
\text { hydrates } \\
\mathbf{( g )}\end{array}$ & $\begin{array}{c}\text { Protei } \\
\mathbf{n} \\
\mathbf{( g )}\end{array}$ & $\begin{array}{c}\text { Fat } \\
\mathbf{( g )}\end{array}$ & $\begin{array}{c}\text { Calcium } \\
(\mathbf{m g})\end{array}$ & $\begin{array}{c}\boldsymbol{\beta} \\
\text { carotene } \\
(\boldsymbol{\mu g})\end{array}$ & $\begin{array}{c}\text { Vitamin } \\
\mathbf{C} \\
(\mathbf{m g})\end{array}$ \\
\hline Agathi mango jujubes & 232.90 & 55.17 & 7.28 & 0.36 & 234.00 & 1152.00 & 36.20 \\
\hline Agathi tomato sauce & 104.55 & 21.51 & 3.20 & 0.61 & 376.50 & 1865.75 & 72.75 \\
\hline Agathi pine apple jam & 459.30 & 111.49 & 2.15 & 0.46 & 251.00 & 1095.90 & 71.30 \\
\hline Agathi sweet pickle & 186.10 & 6.79 & 29.30 & 10.48 & 286.00 & 1093.90 & 35.30 \\
\hline Agathi pickle & 46.35 & 3.34 & 3.345 & 0.03 & 238.30 & 1083.50 & 5.80 \\
\hline Agathi cutlet & 180.00 & 13.64 & 35.40 & 10.39 & 1290.6 & 1541.40 & 35.40 \\
\hline Agathi dry chutney powder & 321.40 & 22.30 & 8.67 & 22.13 & 603.00 & 2740.50 & 90.30 \\
\hline Agathi wet chutney & 299.40 & 31.44 & 7.37 & 21.57 & 590.00 & 2723.50 & 96.40 \\
\hline Agathipathiri & 219.00 & 45.00 & 7.60 & 0.95 & 570.00 & 2700.00 & 84.50 \\
\hline Agathi green gram dosa & 219.4 & 41.28 & 11.14 & 1.13 & 598.80 & 2707.60 & 84.50 \\
\hline Agathi water melon drink & 34.3 & 4.86 & 2.68 & 0.50 & 343.40 & 1620.00 & 51.10 \\
\hline Agathi halva & 238.90 & 27.58 & 5.00 & 2.07 & 227.00 & 901.20 & 34.60 \\
\hline Agathi tomato squash & 151.75 & 31.65 & 4.80 & 0.72 & 573.00 & 2748.00 & 92.25 \\
\hline Agathi melon juice & 150.25 & 33.52 & 4.57 & 0.92 & 585.50 & 2700.00 & 94.25 \\
\hline Agathi cucumber mix & 29.00 & 4.36 & 2.00 & 0.36 & 234.00 & 1080.00 & 39.40 \\
\hline
\end{tabular}

As per TABLE 1, the product with highest calorie content was Agathi pine apple jam $(459.30 \mathrm{Kcal})$ because it contained equal amount of sugar and fruit pulp. It also showed the highest amount of carbohydrates $(111.49 \mathrm{~g})$ in it. The product which gave the lowest energy $(29.00 \mathrm{~K}$ cal.) was Agathi cucumber mix because its ingredients like Agathi and cucumber had low calorie content.

The item which showed lowest amount of carbohydrate (3.34g) was Agathi pickle, since it was made by low carbohydrate food items like Agathi, garlic and tomato.

The protein content of the Agathi cutlet was the highest (35.40g), whereas Agathi cucumber mix showed only $2.00 \mathrm{~g}$ of protein in it. Out of the fifteen products developed incorporating Agathi, the fat rich product was found to be Agathi dry chutney powder which contained $22.13 \mathrm{~g}$ of fat in it.

Agathi is a calcium rich green leafy vegetable. Hence all the products prepared from Agathi were found to be rich in calcium. Among the developed products, Agathi cutlet showed the highest amount of calcium (1290.60mg). All the products prepared with Agathi were also found to be richin $\beta$ carotene. The product which got the highest amount of $\beta$ carotene was Agathi tomato squash. The product rich in vitamin $C$ was Agathi wet chutney $(96.40 \mathrm{mg}$ ) and the product which showed lowest amount of vitamin $\mathrm{C}$ wasAgathi sweet pickle (35.30mg).

\subsection{Shelf life qualities of the developed products}

The shelf life qualities of developed products were assessed for a period of 6 months at room temperature. The findings are given in TABLE 2. 
TABLE.2 Shelf life of Agathi incorporated products (room temperature)

\begin{tabular}{|c|c|c|c|c|}
\hline \multirow[t]{2}{*}{ Product name } & \multirow{2}{*}{$\begin{array}{l}\text { Storage } \\
\text { capacity/g }\end{array}$} & \multicolumn{3}{|c|}{ Variations } \\
\hline & & $\mathbf{A}$ & B & $\mathbf{C}$ \\
\hline Agathi mango jujubes & 100 & $21 / 2$ months & 2 months & 3 months \\
\hline Agathi tomato sauce & 100 & 6 months & 6 months & 6 months \\
\hline Agathi pine apple jam & 100 & 6 months & 6 months & 5 months \\
\hline Agathi sweet pickle & 100 & 3 months & $31 / 2$ months & 3 months \\
\hline Agathi pickle & 100 & 3 months & $21 / 2$ months & 3 months \\
\hline Agathi cutlet & 100 & 1 day & 1 day & 1 day \\
\hline Agathi dry chutney powder & 100 & 1 month & 1 month & 2 weeks \\
\hline Agathi wet chutney & 100 & 1 day & 1 day & 1 day \\
\hline Agathipathiri & 100 & 2 days & 2 days & 2 days \\
\hline Agathi green gram dosa & 100 & 1 day & 1 day & 1 day \\
\hline Agathi halva & 100 & 2 days & 2 days & 3 days \\
\hline Agathi water melon drink & 100 & 1 day & 1 day & 1 day \\
\hline Agathi tomato squash & 100 & 1 month & 1 month & 1 month \\
\hline Agathi lemon juice & 100 & 2 days & 2 days & 2 days \\
\hline Agathi cucumber mix & 100 & 1 day & 1 day & 1 day \\
\hline
\end{tabular}

Three variations of all the Agathi leaves incorporated products (containing 100g products each) were kept for a period of 6 months and examined visually on a daily basis for microbial infestation and noted down the period in which first microbial infiltration was seen. That period was taken as the shelf life of the product under normal room temperature. The products were evaluated organoleptically at the end of each month to find out the changes in their sensory qualities. The products like Agathi wet chutney, Agathipathiri, Agathidosa, Agathi watermelon drink, Agathi halva, Agathi lemon juice and Agathi cucumber mix were organoleptically evaluated at the end of each day, since it contained easily perishable ingredients in them. When a food is considered unsuitable for consumption, it is said to have reached the end of shelf life ${ }^{[16]}$.

Sugar, salt, vinegar and oil were used as the major preservatives in the preparation of the products which determined the shelf life of each product. The products like Agathi jam (6 months), and Agathi tomato sauce (6 months) got the highest shelf life, since these two products contained higher amounts of sugar and salt along with small amounts of vinegar respectively. The next place was occupied by Agathi sweet pickle (3 months) and Agathi pickle (2 1/2 months). High amount of oil and common preservatives like vinegar and salt contributed to the longer shelf life of these products. These products were followed by Agathi tomato squash and Agathi dry chutney powder got the shelf life of 1 month. The dehydration of Agathi leaves led to the longer shelf life of the dry chutney powder (1 month) and placed the product in third position. Other products like Agathi halva, Agathipathiri and Agathi lemon juice had a shelf life of 2 days only and the products Agathi cutlet, Agathi wet chutney, Agathi green gram dosa, Agathi watermelon drink and Agathi cucumber mix had the lowest shelf life of 1 day, since they belonged to the beverages category of easily perishable food items among the incorporated recipes, which contained no artificial colors or chemical preservatives in them.

\subsection{Evaluation of time for the preparation of Agathi incorporated products}

TABLE 3 indicates the time taken for preparing $100 \mathrm{~g}$ of each Agathi incorporated products.

The data depicted in the TABLE 3 revealed that the time taken for cooking Agathi sweet pickle was highest because of longer period of time used for the preliminary preparation of soaking the dates prior to pickle making (7 days 15 minutes).

Least time for production i.e, 10 minutes was taken for the preparation of products like Agathi wet chutney, Agathi water melon drink, Agathi lemon juice and Agathi cucumber mix. This was because all the ingredients were blended or mixed in raw forms to prepare desired product and no cooking was done.

TABLE.3 Evaluation of time taken for the preparation of Agathi incorporated products

\begin{tabular}{|c|c|c|c|c|}
\hline \multirow[b]{2}{*}{ Product name } & \multirow[b]{2}{*}{$\begin{array}{l}\text { Amount } \\
\text { (g) }\end{array}$} & \multicolumn{3}{|c|}{ Time analysis } \\
\hline & & $\begin{array}{l}\text { Preliminary } \\
\text { Preparation time } \\
\text { (minutes/ day) }\end{array}$ & $\begin{array}{l}\text { Cooking time } \\
\text { (minutes) }\end{array}$ & $\begin{array}{l}\text { Total time } \\
\text { (minutes) }\end{array}$ \\
\hline Agathi mango jujubes & 100 & 10 & 25 & 35 \\
\hline Agathi tomato sauce & 100 & 10 & 15 & 25 \\
\hline Agathi pine apple jam & 100 & 10 & 20 & 30 \\
\hline Agathi sweet pickle & 100 & 7 days & 15 minutes & $\begin{array}{c}7 \text { days } 15 \\
\text { minutes }\end{array}$ \\
\hline Agathi pickle & 100 & 10 & 12 & 22 \\
\hline Agathi cutlet & 100 & 15 & 15 & 30 \\
\hline Agathi dry chutney powder & 100 & 5 & 15 & 20 \\
\hline Agathi wet Chutney & 100 & 5 & 5 & 10 \\
\hline Agathipathiri & 100 & 30 & 30 & 60 \\
\hline Agathi green gram dosa & 100 & 8 hours & 8 & $\begin{array}{c}8 \text { hours } \\
8 \text { minutes }\end{array}$ \\
\hline
\end{tabular}


Development And Popularisation Of Agathi Leaves (Sesbaniagrandiflora) Incorporated Food

\begin{tabular}{|c|c|c|c|c|}
\hline Agathi halva & 100 & 2 & 10 & 12 \\
\hline Agathi water melon drink & 100 & 10 & 5 & 15 \\
\hline Agathi tomato squash & 100 & 3 & 10 & 13 \\
\hline Agathi lemon juice & 100 & 10 & - & 10 \\
\hline Agathi cucumber mix & 100 & 10 & - & 10 \\
\hline
\end{tabular}

\subsection{Popularization of the Agathi incorporated products}

Among the 15 developed products, 2 products with highest overall acceptability score were demonstrated and popularized among members of two Kudumbasree units.

\subsubsection{Collection of information about awareness of Agathi}

The questionnaire to check the awareness about Agathi was distributed among the Kudumbasree members and filled by them. Majority of the members gave importance to green leafy vegetables in their diet.

The questionnaire revealed that majority of members was not aware about Agathi leaves; hence they did not cultivate Agathi in their kitchen garden. But, all the members were interested to know about the nutritional and medicinal value of Agathi leaves. A few members were aware about culinary uses of Agathi leaves and were interested to incorporate Agathi leaves in their diet.

\subsubsection{Sensory evaluation of Agathi incorporated products by the Kudumbasree members}

Among the developed products, two products with highest score for overall acceptability were selected for the popularization and the Kudumbasree members evaluated the sensory qualities of the products organoleptically. They were provided with a score card with which they assigned different scores for each product and the results are given in TABLE 4

Among the popularized products, Agathi dry chutney powder obtained the highest score (4.80) for overall acceptability.

\section{TABLE.4 Overall acceptability scores given by the Kudumbasree members}

\begin{tabular}{|l|l|c|c|c|c|c|c|c|}
\hline \multirow{2}{*}{$\begin{array}{c}\text { Sl. } \\
\text { No }\end{array}$} & \multicolumn{1}{|c|}{ Product name } & \multicolumn{6}{|c|}{ Mean score } & \multicolumn{2}{|c|}{$\begin{array}{c}\text { OverallA } \\
\text { ccep- } \\
\text { tability } \\
\text { score } \\
\text { nce }\end{array}$} & $\begin{array}{c}\text { Flavor } \\
\text { Percentageof } \\
\text { overall } \\
\text { acceptibility } \\
\text { ScoreOver } \\
\text { total score }\end{array}$ \\
\hline 1. & $\begin{array}{l}\text { Agathi pineapple } \\
\text { Jam (variation B) }\end{array}$ & 5.00 & 4.80 & 4.80 & 4.40 & 4.60 & 4.70 & 94.00 \\
\hline 2. & $\begin{array}{l}\text { Agathi dry } \\
\text { chutney } \\
\text { powder (variation C) }\end{array}$ & 4.40 & 4.20 & 4.40 & 4.00 & 4.60 & 4.80 & 96.00 \\
\hline
\end{tabular}

In the case of dry chutney powder, it attained good scores for appearance (4.4), flavor (4.20), taste (4.4), texture (4.00) and color (4.60). It obtained a score of 4.80 for overall acceptability through the sensory evaluation done by the panel members, while in popularization; it obtained a score of 4.72 for overall acceptability.

Agathi pineapple jam obtained scores of 5.00, 4.80, 4.80, 4.40and 4.60 for attributes like appearance, flavor, taste, texture and color. Agathi pineapple jam got same scores for overall acceptability in the sensory evaluation given by the judging panel and also by the Kudumbasree members.

Fig.2 showed the details about the percentage of the overall acceptability scores given for each product by the Kudumbasree members. The figure reveals that Agathi dry chutney powder (variation C) showed the highest percentage of the score (96.00) followed by Agathi pine apple jam (94.00).

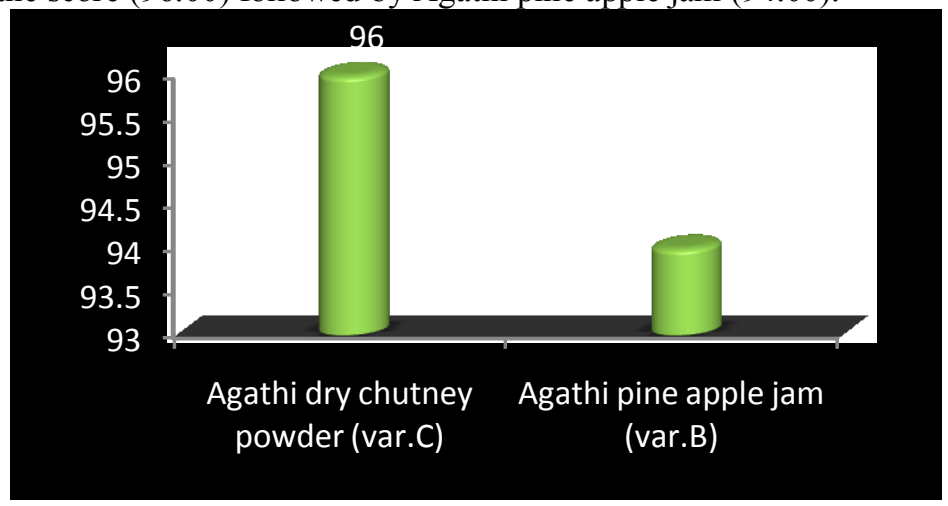

Fig.2 Percentage of overall acceptability scores of the popularized products over the total score 
The scores obtained by Agathi pine apple jam and Agathi dry chutney powder through Sensory evaluation of judging panel and Kudumbasree members are given in Fig.3 and 4. Fig.3 revealed that the score given to Agathi pine apple jam by the judging panel was 94.40 and by the Kudumbasree members was 94.00. The score given to dry chutney powder by the judging panel and the Kudumbasree members were the same (96.00).

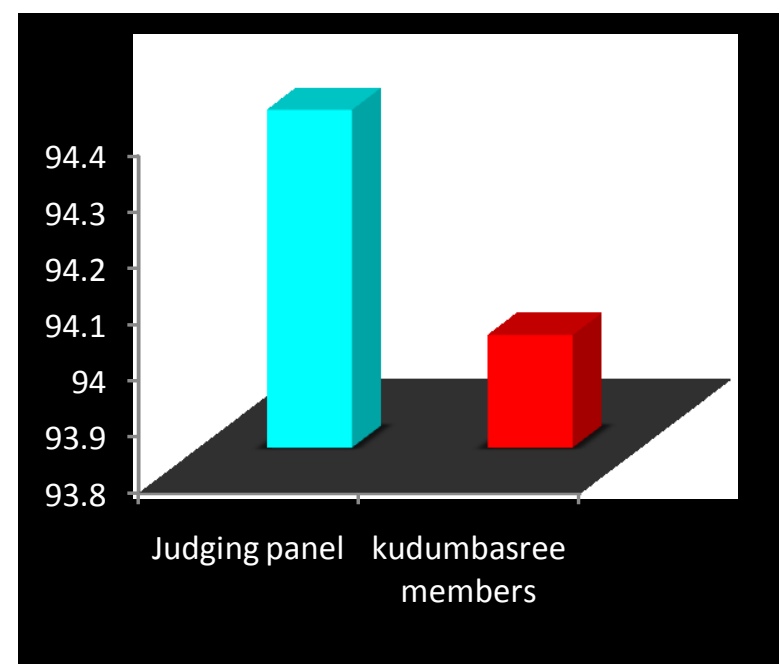

Fig.3 Comparison of percentage of overall acceptability scores of Agathi pine apple jam given by judging panel and Kudumbasree members

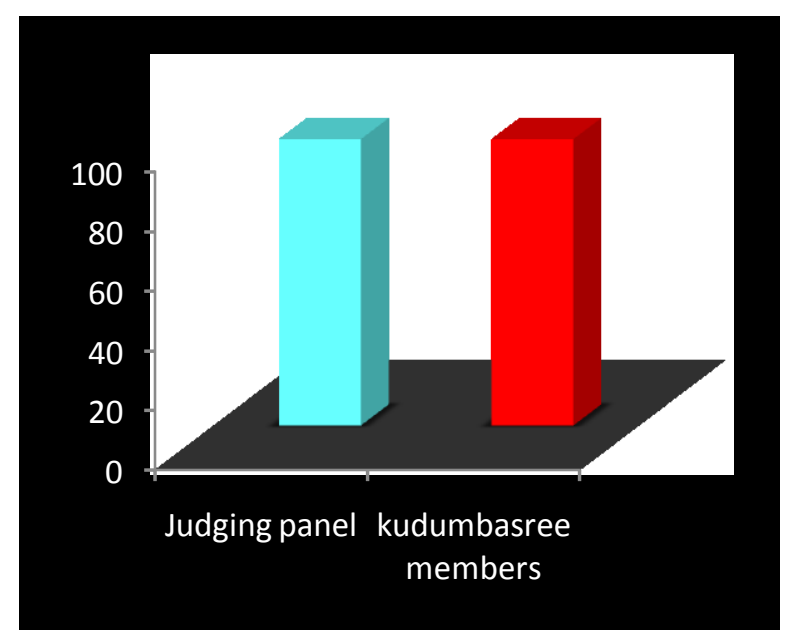

Fig. 4 Comparison of percentage of overall acceptability scores of Agathidry chutney powder given by judging panel and Kudumbasree members

\subsubsection{Collection of feedback}

After the lecture, the feedback of popularization was collected by using a questionnaire. The collected feedback revealed that all the members were interested to incorporate Agathi in their diet. They understood the medicinal and culinary uses of Agathi well and found the lecture very interesting and informative.Their doubts were cleared through a discussion session.

\section{Summary}

Every part of Agathi tree is said to help in the treatment of diseases ${ }^{[17]}$.In order to meet the objectives of the study, fifteen products were prepared by incorporating Agathi leaves. The products were prepared in three variations namely variation $\mathrm{A}$, variation $\mathrm{B}$ and variation $\mathrm{C}$ which contained various proportions of Agathi, incorporated in 20 per cent, 30 per cent and 50 percent in them along with other ingredients for achieving enhanced quality and adequate quantity of the nutrients in the products.

A score card was prepared to select the judging panel of five members. Another five point score card was prepared to evaluate the sensory qualities of the prepared products. Among the prepared variations, variation B of Agathi mango jujubes (4.00), variation C of Agathi tomato sauce (4.28), variation B of Agathi pineapple jam (4.72), variation B of Agathi sweet pickle (4.64), variation A of Agathi pickle (4.20), variation B of Agathi 
cutlet (4.32), variation $\mathrm{C}$ of Agathi dry chutney powder (4.80), variation $\mathrm{C}$ of Agathi wet chutney (4.16), variation A of Agathipathiri (4.20), variation A of Agathi green gram dosa (3.88), variation B of Agathi water melon drink (3.60) variation C of Agathi halva (3.30), variation A of Agathi tomato squash (4.52), variation A of Agathi lemon juice (4.52) and variation $\mathrm{C}$ of Agathi cucumber mix (4.04) were selected as the best variations of each developed Agathi incorporated products.

The prepared products contained, calories within range of $20.35-459.30 \mathrm{~K} \mathrm{cal}$, carbohydrates within the range of 3.34-111.49 g, protein within the range of 1.96-35.40g and fat within a range of $0.03-22.13 \mathrm{~g}$ per $100 \mathrm{~g}$ of each product.. They also supplied adequate amount of calcium $(91.19-1290.60 \mathrm{mg}), \beta$-carotene $(1083.50-$ $2875.50 \mu \mathrm{g})$ and vitamin $\mathrm{C}(5.80-104.00 \mathrm{mg})$. Agathi incorporated products were found to be rich in nutrients especially vitamin $\mathrm{C}$, calcium and $\beta$-carotene, while it supplied less amount of calorie, carbohydrate and fat.

The developed products were analyzed for their shelf life qualities for a period of 6 months at room temperature. Products like Agathi pineapple jam and Agathi tomato sauce got maximum shelf life of 6 months. Among beverages, Agathi tomato squash showed a maximum shelf life of about 1 month.

In time analysis, Agathi sweet pickle required a greater time for preparation (7 days and 15 minutes) while Agathi lemon juice and Agathi cucumber mix required less preparation time of about 5 minute.

Among the developed products, two of the best product variation with highest overall acceptability scores namely Agathi pineapple (4.72) jam and Agathi dry chutney powder (4.80) were popularized among two Kudumbasree units.

For the process of popularization, charts and brochures were prepared. The responses given by the Kudumbasree members showed that they had the interest to cultivate Agathi and also to incorporate Agathi leaves in their daily diet.

\section{CONCLUSION}

Sesbaniagrandifloraor Agathi is not only a green leafy vegetable, but also a medicinal plant. In traditional medicinal system, Agathi is used for curing different diseases like kidney and liver diseases, asthma, nasal catarrh, leprosy, pain etc. The production and consumption of Agathi incorporated recipes, will help to prevent these types of diseases to a remarkable extent.

Most of the people are not aware about the nutritional and medicinal importance of Agathi. Agathi incorporated products are not readily available in markets. In our country, though presently the area under minor vegetables like Agathi is very limited, it is expected that in near future there will be great demand of these vegetables. Hence the current study which highlights the incorporation of Agathi leaves into common foods is beneficial, because of its convenience in cultivation, nutritional benefits, medicinal uses and less expense.

\section{REFERENCES}

[1] Bamji, M. S., Prasad Rao, N and Reddy, N, Textbook of human nutrition(Oxford publishers, New Delhi,2004)

[2] Trivedi, P C, Advances in plant physiology (K I International publishing house Pvt. Ltd., New Delhi, 2006)

[3] Srilakshmi, B, Food science (New age international publishers (PVT), New Delhi, 2009)

[4] Zeng, X and Raun, D, Intelligent sensory evaluation: Methodologies and application (Springer-Verlang Berlin Heidelberg, New York, 2004)

[5] NIN (India), Nutritive value of Indian foods (National Institute of Nutrition, ICMR, Hyderabad, 2011)

[6] Rinsky, G and Rinsky, L H, The pastry chef's companion. A comprehensive Resource Guide for the Baking and Pastry Professionals (John Wiley\& sons Inc, New Jersey, 2009)

[7] Mc Gee, H, On food and cooking: The science and love of the kitchen (Scribner publishers, New York, 2004)

[8] Gehring, A R, The home steading hand book: A back to basic guide to growing your own food, Canning, Keeping chickens, Generating your own energy, crafting herbal medicines and more (Sky horse publishers, New York,2011)

[9] Patil, K, The rice-wheat cropping system of South Asia (Food products Press, Binghamton, 2001)

[10] Sanjeev, K, Pickles, chutneys 'N' more (Popular Prakashan Pvt. Ltd., Mumba, 2009)

[11] Sinto, S, The fitness kitchen: recipes for a fat free life style (Taylor trade publishers, Maryland, 2004)

[12] Lewis, L S, Special diets for special kids: Understanding and implementing a gluten (Future horizons, Inc. Arlington, 1998)

[13] Sathe, A Y, Food analysis (New age international publisher, New Delhi, 1999)

[14] Jeyarani, P, Physico- chemical and functional properties of starches separated from Bombay halva, a traditional Indian confection (Association of food scientists and technologists, Mysore, 1996)

[15] Howarth, J W, The act of staying clean and healthy while travelling (West group publishers, California, 2006)

[16] Dominic, M and Adian, J, Shelf life evaluation of food (Aspen publications, New Delhi, 2000)

[17] Philip, T, Thangam Philip's vegetarian recipes for healthy living (Orient Blackswan Pvt. Ltd. Chennai, 2011) P 17-143 